\title{
Scar endometriosis after caesarean section: a case series and review of literature
}

\author{
Sandeep S. Nanaware*, Prajakta N. Shende, Pradeep Gaikwad, Shalini Valecha
}

Department of Obstetrics \& Gynaecology, ESIC Model Hospital \& PGIMSR cum ODC, Mumbai, Maharashtra, India

Received: 05 February 2016

Accepted: 01 March 2016

\section{*Correspondence:}

Dr. Sandeep S. Nanaware,

E-mail: sandeepnanaware0428@gmail.com

Copyright: $\odot$ the author(s), publisher and licensee Medip Academy. This is an open-access article distributed under the terms of the Creative Commons Attribution Non-Commercial License, which permits unrestricted non-commercial use, distribution, and reproduction in any medium, provided the original work is properly cited.

\begin{abstract}
Endometriosis is defined as extra-uterine localization of ectopic functional endometrial gland and stroma. Cystic or solid tumoral masses caused by endometriosis are named as endometrioma. Although these pathologic conditions mostly encountered in ligaments of uterus, ovaries, pouch of douglos and pelvic peritoneum; endometriosis has also been reported in nose, breast, lung, spleen, gastrointestinal tract, kidney, abdominal wall, but scar endometriomais extremely rare. Scar endometriosis is rare and difficult to diagnose. This condition can be confused with other surgical conditions, however imaging techniques and FNAC are indicated towards better diagnostic approach. Medical treatment is helpful in selected cases but wide excision is the treatment of choice. By presenting this paper, and conducting a review of the literature, we intend to increase the awareness of this rather, rare condition.
\end{abstract}

Keywords: Endometriosis, Granuloma, Hemosiderin, Scar, Lump

\section{INTRODUCTION}

Endometriosis was first described by Rokitansky and it is defined as extra-uterine localization of ectopic functional endometrial gland and stroma and Cystic or solid tumoral masses caused by endometriosis are named as endometrioma. Although this pathologic conditions mostly encountered in ligaments of uterus, ovaries, pouch of douglos and pelvic peritoneum; endometriosis has also been reported in nose, breast, lung, spleen, gastrointestinal tracts, kidney, abdominal wall, but scar endometriomais extremely rare. ${ }^{1,2}$ Its exact prevalence is unknown because it can be diagnosed only after surgery either open or laparoscopy, but it is estimated to be present in $3-10 \%$ of women in the reproductive age group, and $25-35 \%$ of infertile women. In women who had undergone a pelvic operation, scar endometriosis is not rare and its incidence is $1 \%$ after abdominal hysterectomy and $0.03-0.04 \%$ after a Caesarean section. ${ }^{3-}$ ${ }^{6}$ A rare case of cutaneous endometriosis has also been reported Scar endometriosis patients are often referred to the general surgeons because the clinical presentation suggests a surgical cause. ${ }^{7}$ We report seven cases of scar endometriosis, in our Department of Obstetrics \& Gynaecology in 3 year.

By presenting this paper, and conducting a review of the literature, we intend to increase the awareness of this rather, rare condition.

\section{DISCUSSION}

Endometriosis is presence of functioning endometrial tissue outside the uterine cavity, whereas endometrioma is its well circumscribed mass. The various sites for extra pelvic endometriosis are bladder, kidney, bowel, omentum, lymphnodes, lungs, pleura, extremities, umbilicus, hernial sacs, and abdominal wall. ${ }^{1,2}$ Endometriosis involving the abdominal wall is an unusual phenomenon that should be considered in the differential diagnosis of abdominal wall masses in women. $^{8}$ The usual clinical presentation is a painful 
nodule in a parous woman with a history of gynecological or obstetrical surgery. The intensity of pain and size of nodule vary with menstrual cycle.

Table 1: Case reports.

\begin{tabular}{|c|c|c|c|c|c|c|c|c|c|c|}
\hline $\begin{array}{l}\text { Case } \\
\text { no. }\end{array}$ & age & $\begin{array}{l}\text { Obstetric } \\
\text { score }\end{array}$ & $\begin{array}{l}\text { Years } \\
\text { since } \\
\text { casarean } \\
\text { section }\end{array}$ & Presentation & $\begin{array}{l}\text { Swelling } \\
\text { localization }\end{array}$ & $\begin{array}{l}\text { Associated } \\
\text { condition }\end{array}$ & $\begin{array}{l}\mathrm{U} / \mathrm{S} \\
\text { Or } \\
\text { CT }\end{array}$ & FNAC & $\begin{array}{l}\text { Line of } \\
\text { management }\end{array}$ & $\begin{array}{l}\text { Post of } \\
\text { condition }\end{array}$ \\
\hline 1 & 42 & P4L4 & 12 & incidental & $\begin{array}{l}\text { Rt side } \\
\text { upper end } \\
\text { of stich } \\
\text { line }\end{array}$ & $\begin{array}{l}3^{\text {rd }} \text { uv } \\
\text { prolapse }\end{array}$ & $\begin{array}{l}2.5 \times 2 \mathrm{~cm} \\
\text { hypoechic lesion } \\
\text { above rectus } \\
\text { muscle }\end{array}$ & $\begin{array}{l}\text { Sheets and } \\
\text { clusters of } \\
\text { epithelial cells } \\
\text { appear to } \\
\text { form glands, } \\
\text { degenerated } \\
\text { cells, and } \\
\text { hemosiderin } \\
\text { laden } \\
\text { macrophages } \\
\text { suggestive of } \\
\text { endometriosis. }\end{array}$ & $\begin{array}{l}\text { Medial } \\
\text { (GNRH } \\
\text { agonist) } \\
\text { followed by } \\
\text { Vg } \\
\text { hysterectomy }\end{array}$ & $\begin{array}{l}\text { f/w since } 2 \text { year } \\
\text { no recurrence }\end{array}$ \\
\hline 22 & 26 & P1L1A1 & 2.5 & $\begin{array}{l}\text { Lump } \\
\text { anterior } \\
\text { abdominal } \\
\text { wall }\end{array}$ & $\begin{array}{l}\text { Rt lateral } \\
\text { abdominal } \\
\text { wall }\end{array}$ & - & $\begin{array}{l}2 \times 2 \text { hypoechoic } \\
\text { mass }\end{array}$ & $\begin{array}{l}\text { Same as } \\
\text { above }\end{array}$ & medical & Improved \\
\hline 3 & 36 & $\mathrm{P} 212$ & 3 & incidental & $\begin{array}{l}\text { Left side } \\
\text { below } \\
\text { caeserian } \\
\text { scar }\end{array}$ & $\begin{array}{l}\text { Abdominal } \\
\text { Koch }\end{array}$ & $\begin{array}{l}\text { Minimal ascitis } \\
\text { and thicken } \\
\text { mesentery with } \\
\text { mesenteric } \\
\text { lymphadenopathy, } \\
\text { mental thickening } \\
\text { with altered } \\
\text { echogenicity. usg } \\
\text { also showed } \\
\text { hypoechoic } \\
\text { incidental mass of } \\
2 x 2 \text { x } 1 \text { cm at } \\
\text { above rectus } \\
\text { sheath in anterior } \\
\text { abdominal wall }\end{array}$ & yes & $\begin{array}{l}\text { empirical } \\
\text { AKT cat II } \\
\text { and GNRH } \\
\text { agonist }\end{array}$ & Improved \\
\hline 4 & 27 & P1L1 & 1 & $\begin{array}{l}\text { Lump at } \\
\text { anterior } \\
\text { abdominal } \\
\text { wall }\end{array}$ & $\begin{array}{l}\text { Below } \\
\text { caeserian } \\
\text { scar }\end{array}$ & - & $\begin{array}{l}3 \times 2 \times 1 \text { hypoechoic } \\
\text { mass at left scar } \\
\text { site }\end{array}$ & same as above & $\begin{array}{l}\text { Medical } \\
\text { GNRH } \\
\text { agonist } 3 \\
\text { cycles } \\
\text { started but } \\
\text { response was } \\
\text { partial; she } \\
\text { subsequently } \\
\text { underwent a } \\
\text { wide } \\
\text { excision of } \\
\text { the mass. }\end{array}$ & $\begin{array}{l}\text { Histopathological } \\
\text { examination of } \\
\text { the excised mass } \\
\text { confirmed the } \\
\text { diagnosis }\end{array}$ \\
\hline 5 & 25 & P313 & 3.5 & incidental & $\begin{array}{l}\text { Above } \\
\text { stich line }\end{array}$ & - & $\begin{array}{l}4 \times 4 \times 2 \mathrm{~cm} \mathrm{rt} \mathrm{upper} \\
\text { stich line }\end{array}$ & $\begin{array}{l}\text { hemosiderin } \\
\text { laden } \\
\text { macrophages } \\
\text { and } \\
\text { endometrial } \\
\text { glands } \\
\text { suggestive of } \\
\text { endometriosis }\end{array}$ & $\begin{array}{l}\text { Wide } \\
\text { excision }\end{array}$ & $\begin{array}{l}\text { Histopathological } \\
\text { examination of } \\
\text { the excised mass } \\
\text { confirmed the } \\
\text { diagnosis }\end{array}$ \\
\hline 6 & 29 & $\mathrm{P} 212$ & 2 & incidental & $\begin{array}{l}\text { Rt margin } \\
\text { of } \\
\text { surgical } \\
\text { scar }\end{array}$ & & $\begin{array}{l}3 \times 2.5 \mathrm{~cm} \\
\text { hypoechoic mass }\end{array}$ & $\begin{array}{l}\text { Clusters of } \\
\text { epithelial cells } \\
\text { and stroma }\end{array}$ & $\begin{array}{l}\text { Excision } \\
\text { mass }\end{array}$ & $\begin{array}{l}\text { HPE confirmed } \\
\text { endometriosis } \\
\text { and condition of } \\
\text { pts improved }\end{array}$ \\
\hline 7 & 26 & P3L3 & 1 & $\begin{array}{l}\text { Lump at } \\
\text { anterior } \\
\text { abdominal } \\
\text { wall }\end{array}$ & $\begin{array}{l}\text { Rt side of } \\
\text { caeserian } \\
\text { scar }\end{array}$ & - & $\begin{array}{l}2.5 \times 2 \text { hypoechoic } \\
\text { mass }\end{array}$ & $\begin{array}{l}\text { Foci of cluster } \\
\text { of epithelial } \\
\text { mass seen }\end{array}$ & $\begin{array}{l}\text { Medical } \\
\text { (GNRH } \\
\text { agonist } 3 \\
\text { cycle ) }\end{array}$ & Lost follow up \\
\hline
\end{tabular}


Several mechanisms can explain the incidence of scar endometriosis.
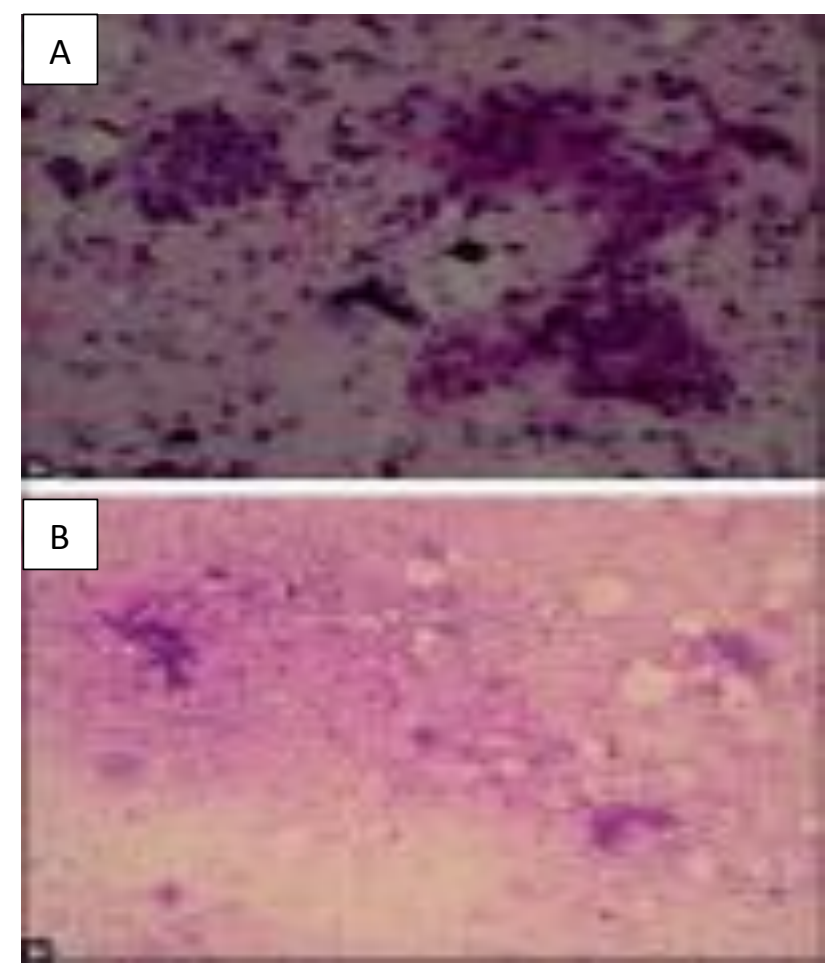

Figure 1: A FNAC smear from the abdominal wall swelling showing epithelial cells and stroma.

Hemosiderin pigment seen in the background $\times 45$; $B$ :

FNAC smear from the abdominal wall swelling showing epithelial cells and stroma (x10).

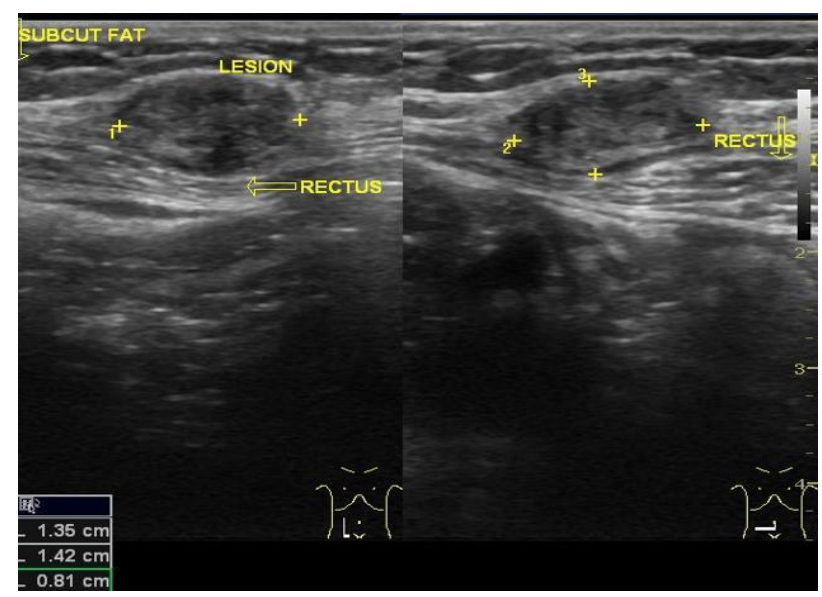

Figure 2: Partly cystic and partly solid intramuscular lesion in the abdominal wall.

Scar endometriosis most commonly occurs after operation on the uterus and tubes. The incidence following cesarean section the incidence is $0.03-0.4 \% .^{9,10}$ The frequency of scar endometriosis has increased in the recent past because of the increasing numbers of cesarean sections and laparoscopies being performed. ${ }^{11}$ Direct mechanical implantation seems to be the most plausible theory for explaining scar endometriosis. During cesarean section, endometrial tissue might be seeded into the wound and under the same hormonal influences, these cells proliferate and form the scar endometrioma. ${ }^{12}$ The endometrial tissue may have certain abilities that make implantation and transplantation possible during pregnancy. The lack of secure closure of the parietal and visceral peritoneum during Caesarean section and reduced care to avoid dissemination of endometrial cells may also be associated with endometriosis at the surgical scar. This scenario, however, is rare and the increased incidence particularly after Caesarean section [0.03\%] does not conform to this rate. ${ }^{5,6,13}$ Metaplasia of peritoneal mesothelial cells which remain in the incision during the initial operation has also been reported. ${ }^{14}$ The theories of lymphatic or vascular dissemination, as well as retrograde menstruation are not widely accepted. ${ }^{15}$ Finally, the recent hypothesis that the presence of endometriosis is related to immunogenetic defects may explain its development via inadequate response of the peritoneal defensive system to the retrograde flow or implantation of endometrial tissue. ${ }^{16,17}$

According to this hypothesis, the strongest risk factor for development of scar endometriosis is early hysterotomy for mid-trimester abortions. ${ }^{18}$ heavy menstrual blood flow and alcohol consumption were positively related to scar endometriosis, and conversely, high parity may be a protecting factor, however, direct implantation of endometrial tissue, cannot explain all cases. There are few cases of primary cutaneous endometriosis without prior surgery, such as at the vulva, perineum, groin, umbilicus, and extremities, as well as nasolacrimal localizations.

In these patients, correct diagnosis depends on careful examination, right questioning and obviously taking endometriosis into consideration. Furthermore, scar endometriosis is a rare entity, and the patients presented with a wide range of duration of cyclical pain from $2 \frac{1}{2}$ years to 10 years of the last cesarean section operation. The usual presenting symptoms of cyclical pain and increase in the size of mass may be due to hormonal influences that cause changes in size, cutaneous bleeding, and bruising. ${ }^{19}$

When a proper pre-diagnosis cannot be achieved, scar endometriosis can be easily mistaken for other surgical conditions such as hernia, hematoma, neuroma, suture granuloma, lipoma, abscess, sebaceous cyst, and neoplastic tissue or even metastatic carcinoma, and patients reach the general surgeon first. ${ }^{20}$ Often the diagnosis of endometriosisis not suggested until after histology has been performed. Correct preoperative diagnosis is achieved in only $20-50 \%$ of these patients. ${ }^{21}$

Imaging procedures help, rather than confirm, in obtaining a differential diagnosis. USG is the best and most commonly used procedure for abdominal masses, given its practicality and low cost. The mass may appear as a hypoechoic and heterogeneous mass with messy 
internal echoes. However, FNAC cytology is a liable method to make the diagnosis of scars, and surgeons must be aware of some diagnoses such as inguinal hernia and re-implantation of potential malignancies during the process. Histology is the Gold standard of diagnosis. It is satisfied if endometrial glands, stroma, and hemosiderin pigment are seen. ${ }^{22}$ In general, diagnosis is easy with a microscopic examination of a standard hematoxylin and eosin-stained slide. Furthermore, the cytologist's experience must be the important point, to clarify diagnosis, and to exclude malignancy. ${ }^{23}$

Medical therapy with danazol, progesterone,Gn-Rh agonists may or may not helpful but recurrence occurs after cessation of the treatment with extreme side effects. ${ }^{24}$ Hence The treatment of choice remains the wide surgical excision to healthy margins, providing both diagnostic and therapeutic intervention. The presence of residual endothelial tissue is associated with recurrences. As ectopic endometrial tissue can theoretically undergo malignant transformation, histologic evaluation is necessary. Malignant change of endometriosis in a cesarean scar (CS) is rare. ${ }^{25}$ Long-standing recurrent scar endometriosis could undergo malignant changes and clinician should be aware.

Only $21.3 \%$ of cases of malignant transformation of endometriosis occur at extragonadal pelvic sites, $4 \%$ of cases in scars after laparotomy. ${ }^{26}$

\section{CONCLUSIONS}

The incidence of scar endometriosis has increased in the recent past because of the increasing numbers of caesarean sections so one should have a high index of suspicion of scar endometriosis, whenever a woman presents with a periodic painful swelling in the abdominal scar, especially with a history of previous gynaecological or obstetric surgery. This condition can be confused with other surgical conditions, however imaging techniques and FNAC are indicated towards better diagnostic approach. Medical treatment is helpful in selected cases but wide excision is the treatment of choice. The patients should be followed up for recurrence.

Funding: Not required

Conflict of interest: None declared

Ethical approval: Not required

\section{REFERENCES}

1. Wheeler JM. Epidemiology and prevalence of endometriosis. Infertil Reprod Med Clin North Am. 1992;3:545-8.

2. Jubanyik KJ, Comite F. Extrapelvic endometriosis. Obstet Gynecol Clin North Am. 1997;24:411-40.

3. Taff L, Jones S. Cesarean scar endometriosis. A report of two cases. J Reprod Med. 2002;47:50-2.

4. Apostolidis S, Michalopoulos A, Papavramidis TS, Papadopoulos VN, Paramythiotis D, Harlaftis N.
Inguinal Endometriosis: Three cases and literature review. South Med J. 2009;102:206-7.

5. Sataloff DM, LaVorgna KA, McFarland MM. Extrapelvic endometriosis presenting as a hernia: clinical reports and review of the literature. Surgery. 1989;105:109-12.

6. Picod G, Boulanger L, Bounoua F, Leduc F, Duval G. Abdominal wall endometriosis after cesarean section: Report of fifteen cases. Gynecol Obstet Fertil. 2006;34:8-13.

7. Wolf Y, Haddad R, Werbin N, Skornick Y, Kaplan O. Endometriosis in abdominal scars: A diagnostic pitfall. Am Surg. 1996;62:1042-4.

8. Celik M, Bulbulogu E, Buyukbese MA, Cetinkaya A. Abdominal wall endometrioma :Localizing in rectus abdominus sheath. Turk j Med Sci. 2004;34;341-343

9. Chatterjee SK. Scar endometriosis: A clinicopathological study of 17 cases. J Obstet Gynaecol. 1980;56:81-4.

10. Koger KE, Shatney CH, Hodge K, McClenathan JH. Surgical scar endometrioma. Surg Gynecol Obstet. 1993;177:243-6.

11. Aydin O. Scar endometriosis - A gynaecologic pathology often presented to the general surgeon rather than the gynaecologist: Report of two cases. Langenbecks Arch Sur.g 2007;392:105-9.

12. Gunes M, Kayikcioglu F, Ozturkoglu E, Haberal A. Incisional endometriosis after cesarean section, episiotomy and other gynecologic procedures.J Obstet Gynaecol Res. 2005;31:471-5.

13. Nominato NS, Prates LF, Lauar I, Morais J, Geber S. Caesarean section greatly increases risk of scar endometriosis. Eur J Obstet Gynecol. 2010;152:83-5.

14. Suginami H. A reappraisal of the coelomic metaplasia theory by reviewing endometriosis occurring in unusual sites and instances. Am J Obstet Gynecol. 1991;165:214-8.

15. Ueki M. Histologic study of endometriosis and examination of lymphatic drainage in and from the uterus. Am J Obstet Gynecol. 1991;165:201-9.

16. Mathur S, Peress MR, Williamson HO, Youmans CD, Maney SA, Garvin AJ, et al. Autoimmunity to endometrium and ovary in endometriosis. Clin Exp Immunol. 1982;50:259-66.

17. Healy JT, Wilkinson NW, Sawyer M. Abdominal wall endometrioma in a laparoscopic trocar tract. Am Surg. 1995;61:962-3.

18. Scott RB, Te Linde RW. Clinical external endometriosis; probable viability of menstrually shed fragments of endometrium. Obstet Gynecol. 1954;4:502-10.

19. Seltzer VL, Benjamin F, Deutsch S. Perimenopausal bleeding patterns and pathologic findings. J Am Med Womens Assoc. 1990;45:132-4.

20. Blanco RG, Parithivel VS, Shah AK, Gumbs MA, Scheinz M, Gerst PH. Abdominal wall endometriomas. Am J Surg. 2003;185:596-8. 
21. Sevdel AV, Sickle SJ, Warner EA, Sax HC. Extrapelvic endometriosis: Diagnosis and treatment. Am J Surg. 1993;177:243-6.

22. Kinkel K, Frei KA, Balleyguier C, Chapron C. Diagnosis of endometriosis with imaging: A review. Eur Radiol. 2006;16:285-98.

23. Meti S, Weiner JJ. Scar endometriosis: A diagnostic dilemma. Eur Clin Obstet Gynaecol 2006;2:62-4.

24. Rivlin ME, Das SK, Patel RB, Meeks GR. Leuprolide acetate in the management of cesarean scar endometriosis. Obstet Gynecol. 1995;85:838-9.
25. Sergent F, Baron M, Le Cornec JB, Scotte M, Mace $\mathrm{P}$, Marpeau L. Malignant transformation of abdominal wall endometriosis: a new case report. J Gynecol Obstet Biol Reprod (Paris). 2006;35(2):18690.

26. Olejek A, Bichalski W, Rembielak-Stawecka B, Ziolkowski A. Adenocarcinoma arising from endometriosis in scar from a cesarean section treated with the use of plastic mesh. Ginekol Pol. 2004;75(10):797-801.

Cite this article as: Nanaware SS, Prajakta SN, Gaikwad P, Valecha S. Scar endometriosis after caesarean section: a case series and review of literature. Int J Reprod Contracept Obstet Gynecol 2016;5:948-52. 